\title{
16 conducting AND EVALUATING CRITICAL INTERPRETIVE RESEARCH: Examining Criteria as a Key Component in Building a Research Tradition
}

\author{
Marlei Pozzebon \\ HEC Montreal
}

\begin{abstract}
The collection, analysis, and interpretation of empirical materials are always conducted within some broader understanding of what constitutes legitimate inquiry and valid knowledge. In the Information Systems field, there are wellknown and widely accepted methodological principles consistent with the conventions of positivism. However, the same is not yet true of interpretive research. The emergence of interpretivism in IS research was advocated by Walsham (1995) and corroborated by a series of special issues in outstanding IS journals. An example of the effort to advance the legitimacy of studies grounded in an interpretive position is the set ofprinciples suggested by Klein and Myers (1999), which applies mostly to hermeneutics. However, because not all interpretive studies are built on a hermeneutical philosophical base, they recommended that other researchers, representing other forms of interpretivism, suggest additional principles. This paper follows in this vein, advocating the timely emergence of a critical interpretive perspective in IS research and pressing the argument that an extended version ofGolden-Biddle and Locke's (1993) criteria is not only appropriate but comprehensive as initial guidelines for conducting and evaluating critical interpretive research.
\end{abstract}

Keywords: Critical interpretive research, research criteria, intensive research, qualitative research

\section{INTRODUCTION}

The motivation, or perhaps I should say the need, for writing this work, grew out of the moment in July 2002 when my thesis proposal defense ended. After presenting to my committee a nonorthodox perspective regarding the prevailing view in North 
American universities (I hold a critical interpretive perspective which combines structuration theory and critical discourse analysis), I found myself with the obligation to better justify the validity of my work when finally defending the thesis. As a result, during the months following the thesis proposal defense, I started to compile interpretive and critical literature, looking for criteria for judging the quality of this type of research. The purpose of this text is to participate in the dialogue about our 20-year perspective on Information Systems research by presenting the provisional ideas I have developed during this time and discussing how to evaluate research carried out from a perspective that I believe is still emergent: critical interpretive.

There are several reasons why the IS field would benefit from an updated review and discussion of the existing criteria for evaluating qualitative research. The use of qualitative methods in IS research is growing rapidly. "As the focus of IS research shifts from technological to managerial and organizational issues, qualitative research methods become increasingly useful," Michael Myers (1997, p. 241) argued when announcing the creation of a special section within MISQ Discovery's World Wide Web archive to support qualitative research. Such increased interest in qualitative research methods is triggering the need for discussions on the criteria for evaluating qualitative research, qualitative not being unambiguously understood since qualitative does not necessarily mean intensive, or interpretive. Behind the term qualitative, a variety of philosophical assumptions and research methods coexist.

Despite the variety of approaches, most of the existing guidelines regarding the evaluation of IS qualitative research up to the 1990s are inspired by underlying philosophical assumptions espoused by a positivistic view (Lee 1989; Yin 1994). Markus and Lee (1999) focus our attention on the danger, still present, ofjudging interpretive research using positivist criteria, and vice versa. Recent initiatives have emerged suggesting a set of principles for the conduct and evaluation of qualitative research from an interpretive standpoint (Klein and Myers 1999; Schultze 2000). I could not find explicit guidelines for evaluating IS critical research. This was corroborated by Klein's assertion that "if one asks which methods can be taught to aspiring critical researchers, one draws almost a blank card. There appears to be no research methods literature on critical research" (1999, p. 21).

In 2004, the WG 8.2 community is celebrating 20 years of efforts toward making an impact on IS research using tools and methods that go beyond those cultivated by mainstream IS research. In keeping with my research into critical and interpretive views, I decided to conduct a review and compile a set of principles for IS researchers that, in addition to taking an interpretive view, seek to develop a critical appreciation of the way in which information technology is involved with organizational activity (Doolin 1998). Briefly, this paper has two goals: first, to reiterate the value to social investigation of a critical interpretive perspective in which social phenomena involving IS or IT are included; second, to review and extend Golden-Biddle and Locke's (1993) criteria, presenting the results as a step forward in drawing up a set of principles for guiding and evaluating critical interpretive research. By criteria, I do not mean a set of fixed standards. Any notion of criteria should be seen as enabling conditions that should only be applied contextually. The terrain upon which judgments are made is continually shifting, and should be characterized by openness, rather than stability and closure (Garrat and Hodkinson 1998). 


\section{WHY CRITICAL INTERPRETIVE?}

My point of departure was the ISWorld.Net special section, "Qualitative Research in Information Systems," edited by Michael Myers, which aims to provide qualitative researchers in IS with useful information on the conduct, evaluation, and publication of qualitative research. This site, and the collection of references it offers, is of great value to researchers seeking to follow interpretive and/or critical work, helping them to legitimate their choices in the eyes of the mainstream IS community. Myers starts by recalling that, just as different people have different beliefs and values, there are different ways ofunderstanding what research is. All research is based on some underlying assumptions about what constitutes valid research and which research methods are appropriate (Myers 1997). These beliefs and values in research have been called paradigms of inquiry (Denzin and Lincoln 1994), theoretical traditions (Patten 1990) or, simply, orientations (Tesch 1990). For instance, in the IS field, research has been classified according to three well-known orientations: positivist, interpretive, and critical (Orlikowski and Baroudi 1991). Although the paradigm debate is starting to provoke a sense of fatigue in many, or simply is "not a very interesting way of thinking about research program differences" (Deetz 1996, p. 194), ${ }^{1}$ classifications according to distinct philosophical assumptions remain useful in helping researchers position themselves clearly and argue for the value of their work. Different designations have emerged, such as post-positivism and post-modernism, showing that the struggle among research groups for identity protection and legitimacy has changed its labels, but not its nature.

Recent theoretical discussions within the IS field have reinforced the benefit of combining different perspectives, especially the interpretive and the critical. For instance, Klein (1999) put forward the "full development of all the potential relationships between interpretivism and critical theory as one of the most fruitful avenues for future research" (p. 22). Similarly, Doolin (1998) points toward a critical interpretive perspective, arguing that interpretive researchers need to consciously adopt a critical and reflective stance in relation to the role that IT plays in maintaining social orders and social relations in organizations. Walsham (1993) advanced a similar position in his leading book about interpretivism in IS research. The research he describes has elements of both the interpretive and critical traditions and, thus, does not fit neatly into either of these categories. Indeed, he argues that constitutive process theories, such as those he espouses, are "an attempt to dissolve the boundaries between such traditions, in emphasizing not only the importance of subjective meaning for the individual actor, but also the social structures which condition and enable such meanings and are constituted by them" (p. 246).

Viewed separately, interpretivism and critical theory are far from being homogenous schools of thought. Klein and Myers (2001) recognize at least two different lines of philosophical thinking underlying the interpretive stream of thinking, drawing our attention to the fact that, even within interpretivism, not all studies should be evaluated according to the same criteria. Regarding critical theory, its foundations are often

${ }^{1}$ Deetz refers to the subjective and objective debate. 
associated with two distinct schools of critical theory: the Frankfurt School of Horkheimer, Adorno, Marcuse and Fromm; and the contemporary critical theory of Habermas. Although these two approaches differ, the differences are seen as subtle (Steffy and Grimes 1986).

Even though calling for a union of critical research and interpretivism, Klein is "very skeptical if current attempts to integrate the two are founded on a clear understanding of their intrinsic connections" (p. 22). He argues that critical theory is much more theory-oriented than interpretivism, and that critical theory carries a strong legacy of Habermas' critical social theory. Yet he acknowledges a theoretical link between critical and interpretive research throughout hermeneutics: critical research emphasizes communicative orientation, which implies interest in human understanding, which, in turn, implies hermeneutics, which is the heart of interpretivism.

Klein's assertions are not incontestable, especially his claim that without an explicit reconstruction of the conceptual foundation, the union of interpretivism and critical research is merely "a matter of convenience, if not desperation" (p. 22). For instance, Doolin argues that to adopt a critical view does not necessarily mean to rely deeply on the critical theory of Habermas and of the Frankfurt School. Being critical may simply imply probing taken-for-granted assumptions inherent in the status quo by being critically reflective, while utilizing whatever theoretical framework is chosen. In combining structuration theory with critical discourse analysis in my own research, I learned from one of the leading figures in critical discourse analysis, Fairclough, that the term critical theory can be used in a "generic sense for any theory concerned with critique of ideology and the effects ofdomination, and not specifically for the critical theory of the Frankfurt School" (1995, p. 20). We can use the term critical without linking it to Habermas or the Frankfurt School.

I believe that to be critically interpretive does not require proper theoretical justifications because both approaches might just be seen as intrinsically related. Interpretive or constructivist approaches aim to produce fine-grained explorations of the way in which a particular social reality has been constructed. Critical approaches aim to focus more explicitly on the dynamics of power, knowledge, and ideology that surround social practices. Far from being incompatible, the boundary between interpretive and critical can be seen as a matter of degree: many constructivist studies are sensitive to power, while critical studies include a concernfor the processes of social construction that underlie the phenomena of interest (Phillips and Hardy 2002). I conclude that IS research may be interpretive and critical without any inherent inconsistency. A number of IS researchers would suggest that it is often hard to avoid being critical when conducting interpretive research (Walsham 1993). Being critically interpretive about IT means that, in addition to understanding the context and process of IS from different interpretations arising from social interactions, researchers will avoid unreflective accounts by connecting these interpretations to broader considerations of social power and control (Doolin 1998).

The connection between interpretation and critical interpretation is nicely illustrated by Alvesson and Skoldberg's (2000) understanding of the different levels of reflection during empirical work (see Table 1). Empirical research starts from the data-constructing level (first level), where researchers make observations, talk to people and create their own pictures of the empirical phenomena. Preliminary interpretations are 
Table 1. Linking Interpretation and Critical Interpretation

\begin{tabular}{|c|c|}
\hline Aspect/Level & Focus \\
\hline $\begin{array}{l}\text { 1. Interaction with empirical } \\
\text { material } \\
\text { 2. Interpretation } \\
\text { 3. Critical interpretation } \\
\text { 4. Reflection on text produc- } \\
\text { tion and language use }\end{array}$ & $\begin{array}{l}\text { 1. Accounts in interviews, observations of situations } \\
\text { and other empirical materials } \\
\text { 2. Underlying meanings } \\
\text { 3. Ideology, power, social reproduction } \\
\text { 4. Own text, claims to authority, selectivity of the } \\
\text { voices represented in the text }\end{array}$ \\
\hline
\end{tabular}

developed, the degree of which is often relatively low or somewhat unclear to the researchers themselves. This material is then subjected to further interpretation of a more systematic kind (second level), guided by ideas that can be related to theoretical frameworks or to other frames of reference. Ideally, researchers would allow the empirical material to inspire, develop, and reshape theoretical ideas. In fact, it is often the case that theoretical views allow the consideration of different meanings in empirical material. "The researcher's repertoire of interpretations limits the possibilities of making certain interpretations" (Alvesson and Skoldberg 2000, p. 250). The interpretation level that follows the interaction with empirical material is a step toward critical interpretation. Critical thinking (third level) and reflexivity (fourth level) stem from interpretive reflection.

\section{DO RESEARCH METHODS IN INTERPRETIVE AND CRITICAL RESEARCH DIFFER?}

Just as there are various philosophical perspectives that can inform qualitative research, so too are there various qualitative research methods. As a matter offact, each research method represents a strategy of inquiry that moves from underlying philosophical assumptions to research design and empirical material interaction (Myers 1997). Viewed broadly, method is a mode and a framework for engaging with empirical material; method connects theoretical frameworks with the production and productive use of empirical material; method is a reflexive activity where theoretical, political, and ethical issues are central (Alvesson and Deetz 2000). Of course the choice of research methods influences the way in which the researcher collects data. Different research methods imply different skills, assumptions, and research practices. The problem related to the choice of a research method is not so much one that takes into account how many methods we employ or if those are of a quantitative or qualitative nature, but rather one that concerns the attempt to achieve coherence over the wholeprocess (Schultze 2000).

Given their concern with understanding actors' meanings, interpretive researchers have often preferred meaning-oriented methods, which differ from positivist researchers' preference for measurement-oriented methods. In particular, from an interpretive perspective, data collection and representation have been accomplished through interviewing (Spradley 1979), ethnography (Van Maanen 1988), participant observation (Myers 1999), and case study (Walsham 1993). Walsham (1993) puts forward a view that the most appropriate method for conducting IS empirical research in the interpretive tradition is the in-depth case study. 
Regarding critical research, the methodological debate is quite unclear. Myers (1999) nominates research action as one of critical researchers' preferred methodological approaches. Klein (1999) not only argues that there appears to be no research methods literature on critical research, but also that this lack of a recognized stock of critical methods provides the primary motivation for critical researchers to borrow interpretive approaches to data collection. Critical researchers often borrow methods like field research, historical analysis, and textual analysis from interpretive research, but utilize them in a context where theoretical ideas are used to encourage political action (Gephart 1999). The distinctions between critical research and interpretivism most clearly are not methodological in nature-both look for meaning-oriented methods - but are related to the recurrent commitment, or lack thereof, to critique of ideology, domination, and status quo.

In my experience conducting doctoral research from a critical interpretive perspective (Pozzebon 2003), I found in critical discourse analysis (CDA) a powerful methodology and perspective for studying social phenomena that involves ways of thinking about discourse (conceptual elements) and ways of treating discourse as data (methodological elements) which is quite distinct from most qualitative approaches (Hardy 2001; Wood and Kroger 2000). CDA has a long history in sociolinguistics (Titscher et al. 2000), is beginning to attract interest in organization studies (Grant et al. 2001), and can be seen as emergent in the IS field as well (Alvarez 2001, 2002; Heracleous and Barret 2001). CDA proved to be an example of a compromise between my interpretive and critical claims. On one hand, CDA reflects the constructivist epistemology underlying my research project. In order to explore the discursive production ofaspects of social reality, discourse analysis is fundamentally interpretive (Phillips and Hardy 2002). On the other hand, because its techniques uncover multiple meanings and representations, and highlight multiple voices and perspectives, CDA becomes very helpful in connecting the discourses of different actors to broader considerations of their social context.

\section{CRITERIA FOR CRITICAL INTERPRETIVE IS RESEARCH}

The historic use of positivistic criteria for evaluating qualitative research reflects the dominance of quantitative research logic in certain social science disciplines. By the 1980s, Lincoln and Guba (1985) proposed four criteria that can be thought of as the development of slightly modified positivist criteria, ${ }^{2}$ more aligned with the worldview of qualitative research. It is noteworthy that several interpretivists argue that such postpositivist criteria are essentially neo- positivist in nature, a sort of "realism reclothed" (Garratt and Hodkinson 1998).

${ }^{2}$ The four criteria—credibility, transferability, dependability, and confirmability—can be seen as equivalent to internal validity, external validity, reliability, and objectivity. Respecting these four criteria would guarantee the trustworthiness of findings from studies using qualitative methods. 
In the IS field, the publication of Klein and Myers' paper can be seen as a response to the call to "discuss explicitly the criteria for judging qualitative, case and interpretive research in information systems" (Klein and Myers 1999, p. 68). They propose a set of principles primarily derived from anthropology, phenomenology, and hermeneutics, acknowledging that other forms of interpretivism also exist. The authors discuss the suitability of such a set of principles, arguing that some authors may feel that, in proposing them "for conducting and evaluating interpretive studies, we are going too far because we are violating the emergent nature of interpretive research, while others may think just the opposite" (p. 68). Their concluding guess is that it is better to have some principles than to have none at all. Complementarily, Garrat and Hodkinson (1998) claim that, although no prespecified criteria can ensure universally valid judgments about any type of research, writing about the ways in which our research can be judged helps "refine and develop our thinking about what doing and judging research entails" (p. 535). In addition, any notion of criteria should be applied contextually and placed continually at risk!

The principles Klein and Myers set forth are not to be mechanistically applied but are open to lively debate about interpretive research standards. Several IS researchers have relied on some of Klein and Myers' principles to validate their qualitative research. Davidson (2002), Gallivan (2001), Hanseth et al. (2001), Henfridson and Holmstrom (2002), and Trauth and Jessup (2000) are some examples. Because their set of principles applies mostly to hermeneutics and not all interpretive studies follow a hermeneutical philosophical base, Klein and Myers recommend that other IS authors, representing other forms of interpretivism, suggest additional principles. For instance, Gopal and Prasad (2000) propose a set of criteria particularly adapted for evaluating symbolic interactionist work, arguing that this research differs from other social constructionist genres, notably hermeneutics and ethnography. A number of IS interpretive researchers-like Davidson (2002), Schultze (2000), Trauth and Jessup (2000), and Walsham and Sahay (1999) — have used Golden-Biddle and Locke's three criteria for ethnographic writing (which does not exclude hermeneutics), as the basis for evaluating their research.

Convincing has been presented as paramount for interpretive researchers relying on ethnography. Van Maanen (1979) outlines the rhetorical effort characterizing the communication between researchers and their audience: "in large measure, our task is rhetorical, for we attempt to convince others that we've discovered something of note, made unusual sense of something, or in weak form, simply described something accurately" (p. 540). Similarly, Silverman (1997) asks, "have the researchers demonstrated successfully why we should believe them?" (p.25). In this vein, Golden-Biddle and Locke consider writing research texts to be about convincing and persuading audiences and about building authorial authority. Trying to answer such a central question from qualitative researchers- "How does ethnographic work convince?"- and positioning the convincingness of ethnographic texts as central, they propose three evaluation criteria: authenticity, plausibility, and criticality. Table 2 shows these three criteria in the first row. The second row presents two additional criteria, recently proposed by Schultze (2000), for evaluating research that, in addition to relying on ethnography, provides a confessional, self-reflexive, and self-revealing account of the researcher's experience. 
Table 2. Interpretive Criteria for Evaluating Ethnography and Reflexive Research

\begin{tabular}{|c|c|c|}
\hline $\begin{array}{l}\text { Interpretive criteria } \\
\text { (for ethnography) } \\
\text { (Golden-Biddle and } \\
\text { Locke 1993) }\end{array}$ & \multicolumn{2}{|c|}{$\begin{array}{l}\text { - Authenticity: Was the researcher there? } \\
\text { - Plausibility: Does the history make sense? } \\
\text { - Criticality: Does the text activate readers to re-examine } \\
\text { assumptions that underlie their work? }\end{array}$} \\
\hline $\begin{array}{l}\text { Interpretive criteria } \\
\text { (for confessional } \\
\text { research) (Schultze } \\
2000)\end{array}$ & $\begin{array}{l}\text { - Self-revealing writing: } \\
\text { Does the text reveal } \\
\text { personal details about the } \\
\text { ethnographer? } \\
\text { - Interlacing actual and } \\
\text { confessional content: Is } \\
\text { autobiographical material } \\
\text { interlaced with actual } \\
\text { ethnographic material? }\end{array}$ & $\begin{array}{l}\text { Reflexivity: Does the author } \\
\text { reveal his/her personal role and } \\
\text { his/her selection of the } \\
\text { voices/actors represented in the } \\
\text { text? (Alvesson and Skoldberg } \\
\text { 2000) }\end{array}$ \\
\hline
\end{tabular}

Table 3. Assembling Criteria for Critical Interpretive Research

\begin{tabular}{|c|c|}
\hline Criteria & $\begin{array}{c}\text { Aspects of Interpretation } \\
\text { (Based on Alvesson and Skoldberg 2000) }\end{array}$ \\
\hline Authenticity & Interaction with empirical material \\
\hline Plausibility & Sound interpretation \\
\hline Criticality & Critical interpretation \\
\hline Reflexivity & Reflection on text production and language use \\
\hline
\end{tabular}

Both Golden-Biddle and Locke's and Schultze's criteria are based on ethnography. Walsham has put forward in-depth case study as the methodological vehicle par excellence to carry out IS interpretive research, as he deems it appropriate "for the view of the nature of knowledge embedded in a broadly interpretive philosophy, which emphasizes the need of detailed understanding of human meanings in context" (1993, p. 247). Walsham also argued that the approach to field research for the case studies largely derives from the ethnographic research tradition, which leads me to conclude that we can differentiate in-depth case study and ethnography as a matter ofdegree. This opens the possibility of adopting Golden-Biddle and Locke's criteria for evaluating indepth case study and other forms of intensive research. Given the lack of other studies (especially IS studies) suggesting criteria for evaluating interpretive research that it is not necessarily of hermeneutic orientation, I propose a new version of Golden-Biddle and Locke's criteria, reviewed and extended, as the basis for evaluating the quality of intensive IS research studies, especially critical interpretive research (see Table 3).

According to Golden-Biddle and Locke, the first two criteria, authenticity and plausibility, are seen as essential. The addition of criticality characterizes the work of a researcher who, in addition to being interpretive, is also critical (I posit criticality also as essential, not an optional criterion as proposed by Golden-Biddle and Locke). I also propose reflexivity (this time optional) as an important aspect in intensive research. 
Reflexivity was inspired by Schultze's confessional research and Alvesson and Skoldberg's (2000) critical view, but also characterizes several variants of poststructural and post-modern studies.

\subsection{Expressing Authenticity}

Authenticity means being genuine to the field experience as a result of "being there" (Golden-Biddle and Locke 1993). Meeting this criterion assures that the researcher was there, and was genuine to the experience in writing up the account. ${ }^{3}$ This is a moment to discuss more purposively the difference that exists between an ethnographic work and an in-depth case study. As Myers (1999) recognizes, one of the distinguishing features of ethnographic research is participant observation: "The researcher needs to be there and live in the organization for a reasonable length of time" (p. 12). In turn, researchers doing case studies strongly rely on in-depth interviews and analysis of archival documents. On-site observation, participant or not, may or may not occur, and when it does occur, its intensity often varies from low to medium, but rarely is very high (otherwise we would be inclined to talk about ethnography and not about in-depth case study). As a result, although researchers conducting in-depth case studies were there to some degree, and might even have gained a certain familiarity with the setting, the being there is not the same as the immersion that characterizes a traditional ethnographic study. Many facts the researcher will report were not directly observed but gathered during interviews and conversations with the social group under study. The closeness to the actions and events of interpretive studies is likely to be higher when the researcher works as a participant observer or action researcher, and lower when the researcher works as an outside observer and interviewer. Researchers will thus report evidence based on their interpretations of other participants' interpretations of the phenomenon investigated (Walsham 1995). ${ }^{4}$

Aware of the differences in degree of being there, I have reflected on the appropriateness of authenticity as a criterion for evaluating in-depth case studies as it seems, indeed, more appropriate for ethnographic work. However, in the absence of another term, I propose to provisionally retain authenticity for evaluating in-depth case studies, but with nuances that respect the nature of this kind of inter action with the field (see Table 4). For instance, instead of proving that we were there, we must prove that we had enough interaction with participants and enough access to archival documents to compensate for the lack of direct immersion during the development of the phenomena under investigation. Consequently, when researchers doing case studies

${ }^{3}$ Schultze offers an interesting comparison between Golden-Biddle and Locke's authenticity and well-known positivist criteria (reliability and validity), reminding me of the risk of constantly recreating a sort of "realism reclothed" instead of reaffirming research values of a quite different ontology (nominalist).

${ }^{4}$ Nandhakumar and Jones (1997) offer a provocative discussion of how a researcher's ability to obtain an understanding of actors' interpretations may be limited in a number of ways. They also put forward alternatives of how the limitations of reporting interpretesons of interpretations can be overcome. 
Table 4. Ways and Examples of Expressing Authenticity

\begin{tabular}{|c|c|c|}
\hline Criteria & Ways to... & Examples from IS Literature \\
\hline \multirow[t]{2}{*}{$\begin{array}{l}\text { (1) Has the } \\
\text { author been } \\
\text { there (in the } \\
\text { field) or had } \\
\text { enough inter- } \\
\text { actions with } \\
\text { participants } \\
\text { to compen- } \\
\text { satefor the } \\
\text { lack ofdirect } \\
\text { immersion? }\end{array}$} & $\begin{array}{l}\text { (1a) Particularizing everyday life from } \\
\text { researchers' direct immersion or from } \\
\text { the interaction with participants and } \\
\text { archival documents (Golden-Biddle } \\
\text { and Locke 1993); demonstrating } \\
\text { familiarity with the vernacular of the } \\
\text { field, describing what members think } \\
\text { about their lives in the field, etc. } \\
\text { (Schultze 2000). }\end{array}$ & $\begin{array}{l}\text { Walsham and Sahay (1999, pp. } \\
59-60) \text { and Schultze (2000, pp. } \\
59-60) \text { provide rich descriptions, } \\
\text { with many quotes, of their } \\
\text { presence in everyday life. }\end{array}$ \\
\hline & $\begin{array}{l}\text { (1b) Delineating the relationship in } \\
\text { the field (Golden-Biddle and Locke } \\
\text { 1993); describing how close the } \\
\text { researchers were, whom they talked to } \\
\text { and observed (Schultze 2000). }\end{array}$ & $\begin{array}{l}\text { In addition to describing the } \\
\text { length of their stay and the } \\
\text { context of their fieldwork, } \\
\text { Walsham and Sahay (1999) add } \\
\text { further material on their role and } \\
\text { attitudes (p. 60). }\end{array}$ \\
\hline $\begin{array}{l}\text { (2) Has the } \\
\text { author been } \\
\text { genuine to } \\
\text { the field } \\
\text { experience? }\end{array}$ & $\begin{array}{l}\text { (2a) Depicting the disciplined pursuit } \\
\text { and analysis of data (Golden-Biddle } \\
\text { and Locke 1993); presenting raw data } \\
\text { such as fieldnotes, documents, and } \\
\text { transcribed interviews, conducting } \\
\text { post hoc respondent validation } \\
\text { (Schultze 2000). }\end{array}$ & $\begin{array}{l}\text { Trauth and Jessup (2000) share } \\
\text { the process of developing their } \\
\text { interpretations openly with } \\
\text { readers, rather than simply } \\
\text { presenting it to them as a } \\
\text { finished product (p. 69). }\end{array}$ \\
\hline
\end{tabular}

particularize everyday life, they are trying to provide sufficient detail, not from deep immersion in the field, but from their interaction with actors deeply immersed in the field. They are telling the reader that they are not reporting facts but their interpretations of other people's interpretations. Table 4 summarizes ways of expressing authenticity in intensive research (ethnography and/or in-depth field study) and offers examples of how IS researchers have dealt with authenticity.

\subsection{Constructing Plausibility}

Plausibility is defined as the ability of the text to connect to the reader's worldview (Walsham and Sahay 1999) and it addresses the rhetorical strategies used to compose a text that positions the work as relevant to the concerns of the intended audience (Schultze 2000). Whereas authenticity is concerned with the conduct of field work, plausibility addresses the write-up phase (Schultze 2000). In order to establish plausibility, researchers should be concerned with two interconnected components. First, they need to make sense, which means to deal with common concerns, establishing connections to the personal and disciplinary backgrounds and experiences of their readers. For instance, the researcher will structure the text in a way that is consistent with the academic article genre, i.e., with specified headings and the use of citations (Schultze 2000). Second, they need to offer a distinctive research contribution to a disciplinary area (Golden-Biddle and Locke 1993). A plausible intensive study will identify gaps in 
the literature or delineate a novel theoretical perspective to justify the research and differentiate its contribution (Schultze 2000).

This latter aspect - convincing that there is a contribution to the field - is one of the most important aspects to be considered. The value of any empirical research depends on the extent to which the author tells us something new and relevant. However, from a critical perspective, we would ask, new and relevant for whom? What is new for one person might not be new for another. More polemically, what is relevant strongly depends on everyone's assumptions, purposes, and expectations (Benbasat and Zmud 1999; Lyytinen 1999). Myers (1999) reminds us that it is essential for researchers to convince the reviewers and editors who serve on the editorial boards of ourjournals that their research contribution is new and relevant.

Plausibility also recalls the dilemma of generalization. According to Klein (1999), the ultimate goal of IS research is to produce some form of knowledge that has relevance outside the context of the original research setting. When the researcher assumes a positivist stance, the status of such knowledge is likely to be law-like generation. In assuming an interpretive stance, the researcher appears more conservative and talks about tendencies (Walsham 1995). The validity of drawing inferences from one or more individual cases depends not on the representativeness of such cases in a statistical sense, but on the plausibility and cogency of the logical reasoning used in describing results from the case, and in formulating inferences and conclusions from those results (Walsham and Waema 1994). Table 5 summarizes ways ofconstructing plausibility and offers examples of how IS researchers have constructed it.

\subsection{Raising Criticality}

Criticality refers to the ability of the text to entice readers to reconsider taken-forgranted ideas and beliefs (Golden-Biddle and Locke 1993). It entails the ability to propose an understanding of ourselves and others in a new and better way, including novel ways of thinking. Criticality can be achieved by challenging readers to pause and think about a specific situation, by provoking them to answer questions, and by guiding readers through novel ways of thinking (Schultze 2000). Although criticality was proposed by Golden-Biddle and Locke as a somehow optional criterion, I propose it as essential to critical interpretive research.

"Good research, from a critical perspective, is one that enables a qualitatively new understanding of relevant fragments of social reality, furnishing new alternatives to social action" (Alvesson and Skoldberg 2000). Critical interpretive studies should necessarily activate such a criterion in order to be able to outline and question prevailing views, to contradict conventional wisdom and multiple viewpoints, which are often in conflict. More attention should be paid not only to multiple narratives that give voice to and allow the construction of multiple worlds, but also to the role of the researcher, of his or her understanding, insights, experiences, and interpretations (link with reflexivity). Multiple narratives will not give us any single representation but they may offer us more interesting ways to think about the organization (Garcia and Quek 1997). Table 6 summarizes ways of raising criticality and offers examples of how IS researchers have been triggering it. 
Table 5. Ways and Examples of Constructing Plausibility

\begin{tabular}{|c|c|c|}
\hline Criteria & Ways to... & Examples from IS Literature \\
\hline \multirow[t]{4}{*}{$\begin{array}{l}\text { (3) Does } \\
\text { the history } \\
\text { make sense } \\
\text { to me? }\end{array}$} & $\begin{array}{l}\text { (3a) Adhering to academic } \\
\text { article genres, using } \\
\text { conventional sections like } \\
\text { method, results, discussion, and } \\
\text { references. }\end{array}$ & $\begin{array}{l}\text { Walsham and Sahay (1999) and } \\
\text { Schultze (2000) organize their papers } \\
\text { with sections like introduction, research } \\
\text { methods, setting description, results, } \\
\text { discussion, and conclusion. }\end{array}$ \\
\hline & $\begin{array}{l}\text { (3b) Drafting the reader } \\
\text { (Golden-Biddle and Locke } \\
\text { 1993); using we to include the } \\
\text { authors and the reader (Walsham } \\
\text { and Sahay 1999). }\end{array}$ & $\begin{array}{l}\text { Walsham and Sahay (1999) use the we } \\
\text { in several situations. }\end{array}$ \\
\hline & $\begin{array}{l}\text { (3c) Legitimating the atypical } \\
\text { (Golden-Biddle and Locke } \\
\text { 1993); showing the scope of the } \\
\text { application of the findings } \\
\text { (Walsham and Sahay 1999); } \\
\text { aligning the findings with } \\
\text { common, everyday experiences } \\
\text { (Schultze 2000). }\end{array}$ & $\begin{array}{l}\text { Walsham and Sahay (1999) show that } \\
\text { their ideas of actor-network theory } \\
\text { could be applied to other technologies } \\
\text { (not only GIS) and other contexts (not } \\
\text { only their Indian case) (p. 61). }\end{array}$ \\
\hline & $\begin{array}{l}\text { (3d) Justifying contestable asser- } \\
\text { tions (Walsham and Sahay } \\
\text { 1999). }\end{array}$ & $\begin{array}{l}\text { Walsham and Sahay (1999) describe a } \\
\text { rich picture and add quotes from } \\
\text { participants in order to support } \\
\text { contestable assertions (p. 61). }\end{array}$ \\
\hline \multirow[t]{2}{*}{$\begin{array}{l}\text { (4) Does it } \\
\text { offer some- } \\
\text { thing dis- } \\
\text { tinctive? }\end{array}$} & $\begin{array}{l}\text { (4a) Differentiating findings-a } \\
\text { singular contribution (Golden- } \\
\text { Biddle and Locke 1993); } \\
\text { showing missing areas in the } \\
\text { past (Walsham and Sahay 1999), } \\
\text { providing the development of a } \\
\text { novel theoretical approach } \\
\text { (Schultze 2000). }\end{array}$ & $\begin{array}{l}\text { Schultze (2000) highlights short- } \\
\text { comings in previous literature and her } \\
\text { contributions with respect to substantive } \\
\text { insights (page } 33 \text { ). }\end{array}$ \\
\hline & $\begin{array}{l}\text { (4b) Building dramatic antici- } \\
\text { pation (Golden-Biddle and } \\
\text { Locke 1993); creating } \\
\text { expectation. }\end{array}$ & $\begin{array}{l}\text { Walsham and Sahay (1999) add a "little } \\
\text { spice to their writing," as described in } \\
\text { page } 61 .\end{array}$ \\
\hline
\end{tabular}


Table 6. Ways and Examples of Raising Criticality

\begin{tabular}{|l|l|l|}
\hline \multicolumn{1}{|c|}{ Criteria } & \multicolumn{1}{|c|}{ Ways to ... } & \multicolumn{1}{c|}{ Examples from IS Literature } \\
\hline $\begin{array}{l}\text { (5) Does the text } \\
\text { motivate the } \\
\text { readers to re- } \\
\text { examine assump- } \\
\text { tions underlying } \\
\text { their own work? }\end{array}$ & $\begin{array}{l}\text { (5a) Carving out room to } \\
\text { reflect (Golden-Biddle and } \\
\text { Locke 1993); including spots } \\
\text { in the text where the reader } \\
\text { stops and reflect about a } \\
\text { specific situation (Schultze } \\
\text { 2000; Walsham and Sahay } \\
\text { 1999). }\end{array}$ & $\begin{array}{l}\text { Walsham and Sahay (1999) and } \\
\text { Schultze (2000) do not use } \\
\text { explicit stop signs, but both } \\
\text { provide implicit illustration of this } \\
\text { strategy. }\end{array}$ \\
\cline { 2 - 4 } & $\begin{array}{l}\text { (5b) Stimulating the recog- } \\
\text { nition and examination of } \\
\text { differences (Golden-Biddle } \\
\text { and Locke 1993); actively } \\
\text { provoking the reader to answer } \\
\text { questions (Walsham and } \\
\text { Sahay 1999). }\end{array}$ & $\begin{array}{l}\text { Walsham and Sahay (1999) invite } \\
\text { readers to critically examine their } \\
\text { own views and approaches (p. 62). }\end{array}$ \\
\cline { 2 - 4 } & $\begin{array}{l}\text { (5c) Imagining new possi- } \\
\text { bilities (Golden-Biddle and } \\
\text { Locke 1993); using metaphors, } \\
\text { stimulating criticality in the } \\
\text { reader (Walsham and Sahay } \\
\text { 1999). }\end{array}$ & $\begin{array}{l}\text { Schultze (2000) challenges readers } \\
\text { to answer questions about their } \\
\text { own assumptions, subjectivity and } \\
\text { objectivity (p. 33). }\end{array}$ \\
\hline
\end{tabular}

\subsection{Experimenting with Reflexivity}

Reflexivity implies reflection on text production and language use and reveals a kind of awareness of the ambiguity of language (Alvesson and Skoldberg 2000). Recalling Table 1, the level of interpretation (interpretation, critical interpretation, reflexive interpretation) each work of empirical research achieves depends, essentially, on each researcher's assumptions and purposes. As outlined by Hardy et al. (2001), work on reflexivity is well developed in areas like sociology of science but has attracted less attention in organization and management theory. I think the same could be said about IS research. Excepting the recent work of Schultze, far less attention exists in our field. In their book dedicated to reflexive methodology, Alvesson and Skoldberg stress that much good qualitative research is unreflexive, often paying much more attention to tasks such as gathering and analyzing data than to different elements of reflexivity, both during the process of research and in the final textual product. Reflexivity was defined by Clegg and Hardy as "ways of seeing which act back on and reflect existing ways of seeing" (1996, p. 4). Reflexive research often includes researchers in the subject matter they are trying to understand. Hardy et al. (2001) complement this notion: "we cannot confine our attention to the relationship between researchers and the research subject, but must also examine the relationship between researchers and the research network of which they are part" (p. 533). 
Table 7. Ways and Examples of Experimenting with Reflexivity

\begin{tabular}{|l|l|l|}
\hline \multicolumn{1}{|c|}{ Criteria } & \multicolumn{1}{|c|}{ Ways to ... } & \multicolumn{1}{c|}{ Examples from IS literature } \\
\hline $\begin{array}{l}\text { (6) Does the } \\
\text { author reveal } \\
\text { his/her per- } \\
\text { sonal role and } \\
\text { personal } \\
\text { biases and } \\
\text { assumptions? }\end{array}$ & $\begin{array}{l}\text { (6a) Self-revealing writing } \\
\text { (Golden-Biddle and Locke 1993); } \\
\text { describing researcher's personal } \\
\text { role (Alvesson And Skoldberg } \\
\text { 2000); using personal pronouns, } \\
\text { revealing personal details about } \\
\text { the researcher (Schultze 2000). }\end{array}$ & $\begin{array}{l}\text { Schultze (2000) uses "I" in abun- } \\
\text { dance in the descriptions of her own } \\
\text { informed practices as well as in the } \\
\text { excerpts from the field notes. She } \\
\text { also presents herself, giving infor- } \\
\text { mation about age, gender, race, etc. }\end{array}$ \\
\cline { 2 - 4 } & $\begin{array}{l}\text { (6b) Interlacing actual and } \\
\text { confessional content (Golden- } \\
\text { Biddle and Locke 1993; Schultze } \\
\text { 2000). }\end{array}$ & $\begin{array}{l}\text { Schultze (2000) avoids over- } \\
\text { emphasis on self-reflexive and auto- } \\
\text { biographical material by describing } \\
\text { participants' practices after de- } \\
\text { scribing her own practices (p. 34). }\end{array}$ \\
\cline { 2 - 4 } & $\begin{array}{l}\text { (6c) Qualifying personal biases } \\
\text { (Golden-Biddle and Locke 1993); } \\
\text { describing researcher's selection } \\
\text { of the voices/actors represented in } \\
\text { the text (Alvesson and Skoldberg } \\
\text { 2000); disclosing details like } \\
\text { mistakes made (Schultze 2000). }\end{array}$ & $\begin{array}{l}\text { Schultze (2000) provides examples } \\
\text { of mistakes she made with respect to } \\
\text { contaminating the data (p. 34). }\end{array}$ \\
\hline
\end{tabular}

Schultze defined the reflexive dimension of her work with two elements: selfrevealing writing and the interlacing of actual ethnographic material and confessional content. A self-revealing text demands a personalized author, the use of personal pronouns to consistently highlight the point of view being represented, and the construction of the researcher as a reasonable yet fallible individual with whom the audience can identify. Regarding the second feature, confessional writing interlaces the actual ethnographic content with the confessional material, meaning that any statement about the foreign culture is also a statement about the ethnographer' and the reader's culture.

To Holland (1999), reflexivity involves reflecting on the way research is carried out and understanding how the process of doing research shapes its outcomes. This calls into discussion the responsibility of researchers to declare their biases. Hardy et al. point out that, from an interpretive standpoint, this does not mean to remove such biases, but to render them visible though personal disclosure, so that readers can take them into account. In other words, any research is seen as one representation among many possible representations, and researchers present their representations for interpretation by the reader. Table 7 summarizes ways of experimenting with reflexivity and offers examples of how IS researchers have been undertaking it.

\section{CONCLUDING REMARKS}

By choosing emergent ways of making sense of IS phenomena, we assume some important risks and cope with many difficulties. Critical and interpretive studies are increasing in number and are starting to be regularly published at IS conferences, in 
journals, and in books, but they do not yet have the wide acceptance that positivist studies enjoy. As Walsham outlines, any theoretical choice is always "a way of seeing and a way of not-seeing" (1993, p. 6). The same applies to methodological choices: each one is a way of interacting with empirical material that is guided by the researcher's background, bias, and world-view, with pros and cons. As researchers, we will always deal with some degree of uncertainty about our choices and interpretations, which are not created, shared, or applied in a social vacuum, but are involved in communication, interpersonal relations, identity construction, and convincing others (and ourselves) that our propositions are sound (Alvesson and Skoldberg 2000).

In this paper, I put forward the argument that critical interpretive research is an emerging and valuable perspective on IS research. How can we, if we so choose, determine which set of criteria to adopt in conducting and evaluating critical interpretive work? The fact that critical interpretive research is essentially constructivist and emergent does not mean that looking for evaluative criteria and judging the quality are not appropriate. Writing about ways to develop andjudge any type of intensive research helps refine and develop our thinking about what conducting and evaluating intensive research leads to and also serves as a device for sharing ideas with others about these things. Most important, to discuss a set of criteria for conducting and evaluating intensive research represents a key component in building a research tradition of which we are a part. "Established approaches to doing and judging research are our collective prejudices, neither to be slavishly accepted not willfully rejected, but which should be placed continuously at risk" (Garratt and Hodkinson 1998, p. 535).

In this paper, I have also tried to trace a picture ofdifferent sets of criteria that have emerged regarding the wide interpretive perspective. What complicates this exercise is that it is difficult to treat equally categories like hermeneutical philosophical base (Klein and Myers 1999), symbolic interactionist work (Gopal and Prasad 2000), ethnographic writing (Golden-Biddle and Locke 1995) or confessional research (Schultze 2000). For instance, while hermeneutic can be defined as a broad theoretical tradition, ethnography can be defined as a research strategy. The two are far from being mutually exclusive. Future research can refine the above debate by clarifying distinctions regarding criteria vis-à-vis ontological or epistemological assumptions, i.e., broad paradigms, perspectives, or traditions (e.g., interpretivism); criteria vis-à-vis theoretical traditions (e.g., hermeneutic or symbolic interactionism); and criteria vis-à-vis research strategies (e.g., case study or ethnography). ${ }^{5}$

Analyzing the nature of criteria in qualitative research, Garratt and Hodkinson (1998) develop a provocative argument: "criteria can only be located in the interaction between research findings and the critical reader of those findings" (p. 515). They assume that most writing about the ways in which research should be judged is concerned almost exclusively with the ways in which research was done, and does not take into account the ways in which the standpoint of the reader will influence their judgment of that research. As a result, all criteria for judging research quality contain within them a defining view of what research is, and any attempt to preselect the criteria against which a piece of research is to be judged is also "predetermining what the nature

${ }^{5}$ I thank Charo Rodriguez for her insightful comments on this topic. 
of that piece of research should be" (p. 525). The authors are not saying that qualitative judgments in research cannot be made but, rather, insisting that the idea of deliberately choosing any list of universal criteria in advance of reading a research report is antithetical to the process of understanding the experience. All these thoughts about research, quality of research, criteria for research, and building a research tradition, albeit partly subjective, are drawn from the evolving wisdom within the research network of which we are a part.

\section{ACKNOWLEDGEMENTS}

The author would like to thank Charo Rodriguez, Alain Pinsonneault, and two anonymous reviewers for their helpful comments in the first drafts of this paper, and HEC Montreal for its research support.

\section{REFERENCES}

Alvarez, R. "Confessions of an Information Worker: A Critical Analysis of Information Requirements Discourse," Information and Organization (12), 2002, pp. 85-107.

Alvarez, R. "It Was a Great System. Face-Work and the Discursive Construction of Technology During Information Systems Development," Information Technology \& People (14:4), 2001, pp. 385-405.

Alvesson, M., and Deetz, S. Doing Critical Management Research, London: Sage Publications, 2000.

Alvesson, M., and Skoldberg, K. Reflexive Methodology: New Vistas for Qualitative Research, London: Sage Publications, 2000.

Benbasat, I., and Zmud, R. W. "Empirical Research in Information Systems: The Practice of Relevance," MIS Quarterly (23:1), 1999, pp. 3-16.

Clegg, S., and Hardy, C. "Some Dare Call Into Power," in S. Clegg, C. Hardy, and W. Nord (Eds.), Handbook of Organization Studies, London: Sage Publications, 1996.

Davidson, E. J. "Technology Frames and Framing: A Socio-Cognitive Investigation of Requirements Determination,” MIS Quarterly (26:4), 2002, pp. 329-358.

Denzin, N. K., and Lincoln, Y. S. Handbook of Qualitative Research, Newbury Park, CA: Sage Publications, 1994.

Deetz, S. "Describing Differences in Approaches to Organization Science: Rethinking Burrell and Morgan and Their Legacy," Organization Science (7:2), 1996, pp. 191-207.

Doolin, B. "Information Technology as Disciplinary Technology: Being Critical in Interpretive Research on Information Systems," Journal of Information Technology (13), 1998, pp. 301 311.

Fairclough, N. Critical Discourse Analysis-The Critical Study of Language, London: Longman, 1995.

Gallivan, M. J. "Organizational Adoption and Assimilation of Complex Technological Innovations: Development and Application of a New Framework," The Data Base for Advances in Information Systems (32:3), 2001, pp. $51-84$.

Garcia, L., and Quek, F. "Qualitative Research in Information Systems: Time to Be Subjective?" in A. S. Lee, J. Liebenau, and J. I. DeGross (Eds.), Information Systems and Qualitative Research, London: Chapman \& Hall, 1997, pp. 444-466.

Garratt, D., and Hodkinson, P. "Can There Be Criteria for Selecting Research Criteria? A Hermeneutical Analysis of an Inescapable Dilemma," Qualitative Inquiry (4:4), 1998, pp. 515-539. 
Gephart, R. "Paradigms and Research Methods," Research Methods Forum (4), 1999, pp. 1-11. Golden-Biddle, K., and Locke, K. "Appealing Work: An Investigation of How Ethnographic Texts Convince," Organization Science (4), 1993, pp. 595-616.

Gopal, A., and Prasad, P. "Understanding GDSS in Symbolic Context: Shifting the Focus from Technology to Interaction," MIS Quarterly (24:3), 2000, pp. 509-546.

Grant, D., Keenoy, T., and Oswick, C. "Organizational Discourse-Key Contributions and Challenges," International Studies of Management and Organization (31:3), 2001, pp. 5-24.

Hanseth, O., Ciborra, C. U., and Braa, K. "The Control Devolution: ERP and the Side Effects of Globalization," The Data Base for Advances in Information Systems (32:4), 2001, pp. 34-46.

Hardy. C. "Researching Organizational Discourse," International Studies in Management and Organization (31:3), 2001, pp. 25-47.

Hardy, C., Phillips, N., and Clegg, S. "Reflexivity in Organization and Management Theory: A Study of the Production of the Research 'Subject',' Human Relations (54:5), 2001, pp. 531560.

Henfridson, O., and Holmstrom, H. "Developing E-Commerce in Internetworked Organizations: A Case of Customer Involvement Throughout the Computer Gaming Value Chain," The Data Base for Advances in Information Systems (33:4), 2002, pp. 38-50.

Heracleous, L., and Barrett, M. "Organizational Change as Discourse: Communicative Actions and Deep Structures in the Context of Information Technology Implementation," Academy of Management Journal (44:4), 2001, pp. 755-778.

Holland, R. "Reflexivity," Human Relations (52:4), 1999, pp. 463-485.

Klein, H. K. "Knowledge and Research in IS Research: from Beginnings to the Future," in O. Ngwenyama, L. Introna, M. D. Myers, and J. I. DeGross (Eds.), New Information Technologies in Organizational Processes: Field Studies and Theoretical Reflections on the Future of Work, Boston: Kluwer Academic Publishers, 1999, pp. 13-25.

Klein, H. K., and Myers, M. D. "A Classification Scheme for Interpretive Research in Information Systems," in E. M. Trauth (Ed.), Qualitative Research in IS: Issues and Trends Hershey, PA: Idea Group Publishing, 2001, pp. 218-239.

Klein, H. K., and Myers, M. D. "A Set of Principles for Conducting and Evaluating Interpretive Field Studies in Information Systems," MIS Quarterly (23:1), 1999, pp. 67-93.

Lee, A. “A Scientific Methodology for MIS Case Studies," MIS Quarterly, 1989, pp. 33-50.

Lincoln, Y. S., and Guba, E. G. Naturalistic Inquiry, New York: Sage Publications, 1985.

Lyytinen, K. "Empirical Research in Information Systems: On the Relevance of Practice in Thinking," MIS Quarterly (23:1), 1999, pp. 25-27.

Markus, M. L., and Lee, A. S. "Special Issue on Intensive Research in Information Systems: Using Qualitative, Interpretive, and Case Methods to Study Information Technology," MIS Quarterly (23:1), 1999, pp. 35-38.

Myers, M. D. "Investigating Information Systems with Ethnographic Research," Communications of AIS (2:23), 1999, pp. 2-19.

Myers, M. D. "Qualitative Research in Information Systems," MIS Quarterly (21:2), 1997, pp. 241-242.

Nandhakumar, J., and Jones, M. "Too Close for Comfort? Distance and Engagement in Interpretive Information Systems Research,” Information Systems Journal, 7, 1997, pp. 109-31.

Orlikowski, W. J., and Baroudi, J. J. "Studying Information Technology in Organizations: Research Approaches and Assumptions," Information Systems Research (2:1), 1991, pp. 1-28.

Patton, M. Q. Qualitative Evaluation and Research Methods, Newbury Park, CA: Sage Publications, 1990.

Phillips, N., and Hardy, C. Discourse Analysis-Investigating Processes of Social Construction, London: Sage Publications, 2002. 
Pozzebon, M. The Implementation of Configurable Technologies: Negotiations between Global Principles and Local Contexts, Unpublished Ph.D. Dissertation, McGill University, 2003.

Schultze, U. "A Confessional Account of an Ethnography about Knowledge Work," MIS Quarterly (24:1), 2000, pp. 3-41.

Silverman, D. "The Logic ofQualitative Research," in J. Hassard, and M. Parker (Eds.), Context and Method in Qualitative Research, London: Sage Publications, 1997.

Spradley, J. P. The Ethnographic Interview, New York: Holt Reinhart \& Winston, 1979.

Steffy, B. D., and Grimes, A. J. "A Critical Theory of Organization," Academy of Management Review (11:2), 1986, pp. 322-336.

Tesch, R. Qualitative Research: Analysis, Types and Software Tools, London; Falmer, 1990.

Titscher, S., Meyer, M., Wodak, R., and Vetter, E. Methods of Text and Discourse Analysis, London: Sage Publications, 2000.

Trauth, E. M., and Jessup, L. M. "Understanding Computer-mediated Discussions: Positivist and Interpretive Analyses of Group Support System Use," MIS Quarterly (24:1), 2000, pp. 43-79.

Van Maanen, J. "The Fact of Fiction in Organizational Ethnography," Administrative Science Quarterly (24), 1979, pp. 539-550.

Van Maanen, J. Tales of the Field, Chicago: University of Chicago Press, 1988.

Walsham, G. Interpreting Information Systems in Organizations, Chichester, England: John Wiley and Sons, 1993.

Walsham, G. "Interpretive Case Studies in IS Research: Nature and Method," European Journal of Information Systems (4), 1995, pp. 74-81.

Walsham, G., and Sahay, S. "GIS for District-level Administration in India: Problems and Opportunities," MIS Quarterly (23:1), 1999, pp. 39-65.

Walsham, G., and Waema, T. "Information Systems Strategy and Implementation: A Case Study of a Building Society," ACM Transactions on Information Systems (12:2), 1994, pp. 150-173.

Wood, L. A., and Kroger, R. O. Doing Discourse Analysis—Methods for Studying Action in Talk and Text, London: Sage Publications, 2000.

Yin, R. K. Case Study Research, Design and Methods, Newbury Park, CA: Sage Publications, 1994.

\section{ABOUT THE AUTHOR}

Marlei Pozzebon is an assistant professor at HEC Montreal. She received her Ph.D. from McGill University in 2003. Her research interests are the political and socio-cultural aspects of information technology implementation, the use of structuration theory and critical discourse analysis in the information systems field, business intelligence and social responsibility, and the role of information technology in developing countries. Prior to joining HEC, Marlei worked at three Brazilian universities and she also held positions such as consultant and systems analyst for at least 13 years. She has published papers in Journal of Management Studies and presented papers at the Academy of Management Conference, the International Conference of Information Systems, and the European Group on Organization Studies, among others. Marlei Pozzebon can be reached at Marlei.pozzebon@hec.ca. 